\title{
O teatro do grotesco como cenário da desconstrução do Brasil
}

\author{
Freda INDURSKY • \\ Universidade Federal do Rio Grande do Sul (UFRGS)
}

RESUMO

O presente artigo analisa, à luz da Análise do Discurso, a fala pública do presidente do Brasil, eleito em 2018. Uma distinção entre seguidores e apoiadores é estabelecida com base no jogo cruzado das formações imaginárias, através dos modos de dizer do governante em relação a esses dois grupos e também em relação a si mesmo. Seus seguidores são visíveis e ruidosos, vestidos de verde-amarelo, identificando-se plenamente com seu presidente, nele espelhando suas práticas. Eles produzem o efeito de uma massa

\section{○}

\section{OPEN ACCESS}

\section{EDITADO POR \\ - Evandra Grigoletto (UFPE) \\ - Bethania Mariani (UFF) \\ - Gian Luigi De Rosa (UNIROMA) \\ AVALIADO POR \\ - Claudia Pfeiffer (UNICAMP) \\ - Solange Leda Gallo (UNISUL) \\ DATAS \\ - Recebido: 25/10/2020 \\ - Aceito: 16/11/2020 \\ - Publicado: 17/12/2020}

\section{COMO CITAR}

Indursky, F. (2020). O teatro do grotesco como cenário da desconstrução do Brasil. Revista da Abralin, v. 19, n. 3, p. 365-388, 2020. de apoiadores, enquanto os apoiadores efetivos, em sua invisibilidade, sustentam seu presidente no poder para que ele realize as reformas próprias a um sistema neoliberal. Esse governo está desconstruindo o patrimônio cultural e ambiental e promovendo o desmonte da saúde e da educação. Esse presidente, que chegou ao poder por instrumentos democráticos, aproveita-se das liberdades próprias à democracia, aproximando-se, cada vez mais, dos saberes fascistas. Se, por um lado, é impossível ignorar tais avanços, por outro, não é possível afirmar que o atual governo instituiu um Estado fascista. A escuta discursiva mostrou que esse discurso se materializa em uma língua política fascista, inscrita em um regime de repetibilidade, que faz ressoar saberes do fascismo. Além disso, essa língua - desabrida e truculenta - pratica violência verbal. Seu léxico, extremamente vulgar, expõe sua homofobia e misoginia. Seu discurso se materializa através de uma fraseologia marcada por uma sintaxe rudimentar que produz frases curtas, truncadas e/ou desestruturadas. Sua língua é uma metáfora de seu governo.

\section{RÉSUMÉ}

Cet article examine, dans une perspective discursive, le discours du 


\section{REVISTA DA ABRALIN}

président élu en 2018, au Brésil. Une distinction entre défenseurs et supporteurs est établit sur la base du jeux des formations imaginaires, observées à travers ses façons de dire à propos de ces deux differénts types d'adeptes et à propos de soi même. Ses défenseurs, visibles et bruyants, habillés en verd et jaune, s'identifient entièrement avec leur président, en reproduisant ses pratiques. Ils produisent l'effet d'une masse de supporteurs, tandis que les vrais supporteurs se maintiennent invisibles, tout en soutenant leur président, pourvu qu'il réalise des réformes inhérentes à un système capitaliste néoliberal. Ce gouvernement s'acharne contre le patrimoine culturel et environnemental et démonte la santé et l'éducation publiques. Ce président, qui est arrivé au pouvoir par un processus démocratique, profite de la liberté propre à la démocratie pour s'approcher au plus des savoirs fascistes. Si, d'un côté, il est impossible d'ignorer cette avancée vers le fascisme, d'autre part, il n'est pas possible d'affirmer que l'actuel système politique brésilien soit fasciste. L'écoute discursive a montré que ce discours se matérialise à travers une langue fasciste, inscrite dans un régime de répétibilité, qui fait résonner des savoirs fascistes. En outre, cette langue - truculente et débridée - pratique la violence verbale. Son lexique, extrêmement vulgaire, expose son homophobie et misogynie. Sa mise en discours se fait sur une phraséologie marquée par une syntaxe rudimentaire, aux phrases courtes, tronquées e/ou destructurées. Cette langue est une métaphore de son gouvernement.

\section{PALAVRAS-CHAVE}

Seguidores. Apoiadores. Língua fascista. Formações imaginárias.

Modos de dizer.

\section{MOTS-CLÉS}

Défenseurs. Supporteurs. Langue fasciste. Formations Imaginaires.

Façons de dire.

\section{Introdução}




\section{REVISTA DA ABRALIN}

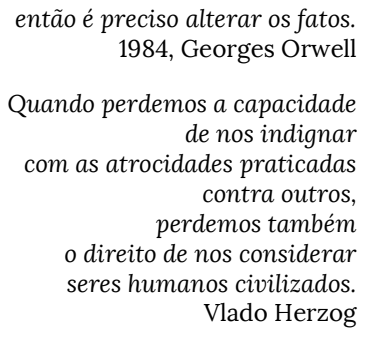

Em texto anterior (INDURSKY, 2019), analisando os encaminhamentos de votos dos deputados federais por ocasião da admissão do processo de impeachment de Dilma Rousseff, comparei aquelas declarações a uma farsa e tomei aquele ritual como uma peça de Teatro do Absurdo.

Quatro anos se passaram. Entre as muitas coisas que sucederam desde então, aconteceram as eleições presidenciais de 2018 e o tenente-capitão ${ }^{1}$, reformado por tentativa de explodir um alvo no interior do quartel em que servia para pressionar por aumento de soldo, foi eleito presidente do Brasil. Sim. Aquele mesmo deputado que, na votação do impeachment de Dilma Rousseff, homenageou o Coronel Ustra, torturador de Dilma durante a ditadura militar. Aquele mesmo deputado que traduziu o slogan da Alemanha nazista - Deutchland uber alles (Alemanha acima de tudo) - ao votar pelo impeachment, alegando fazê-lo em nome do Brasil acima de tudo.

Hoje, não vivemos mais uma farsa, pois esse gênero provoca o riso, mesmo que amargo. E o desgoverno que aí está não se parece com o Teatro do Absurdo. Já ultrapassamos de longe as características desse gênero teatral. Hoje, o Brasil se assemelha a uma nave desgovernada que remete ao Teatro do Grotesco ${ }^{2}$, o qual, em lugar do riso, provoca ranger de dentes. Esse teatro serve de cortina de fumaça para opacificar os atos de desconstrução do Brasil. São muitas as frentes que estão sendo atacadas: as reservas naturais, as reservas indígenas, os indígenas, as matas nativas, a educação, a ciência, a saúde, a cultura, os programas sociais, a Previdência...Essas são as condições de produção que presidem a escrita deste ensaio.

\section{1. (Des)governo, adeptos e jogo cruzado de formações imaginárias}

\footnotetext{
${ }^{1}$ Sua patente no exército era a de tenente. Nas Forças Armadas brasileiras, ao ser reformado, o militar sai com o posto imediatamente superior. No caso aqui em tela, portanto,o tenente reformou-se como capitão. Neste artigo, ele será nomeado como tenente-capitão, capitão, capitão-presidente, (des)presidente. Essas designações foram estabelecidas em função das diferentes questões que serão analisadas.

${ }^{2} \mathrm{O}$ teatro do grotesco põe em cena o caos do indivíduo e do corpo social, desenhando uma caricatura da própria existência humana e de seus dirigentes. O exagero e as excentricidades postos em cena representam uma realidade disforme, até mesmo monstruosa, da sociedade representada.
} 


\section{REVISTA DA ABRALIN}

Mas, se o tenente-capitão pode desconstruir todo um patrimônio construído ao longo de muitas décadas e por inúmeros e sucessivos governos, aí incluídos os governos da ditadura militar, é porque tem adeptos. Cabe, então, perguntar: quem são eles?

Para refletir sobre essa questão, vou mobilizar as Formações Imaginárias, tal como formuladas por Pêcheux (2019 [1969], p.338-44), pois elas iluminarão as condições de produção do discurso posto em circulação em nossos dias:

Quem sou eu para que me falem assim? Quem sou eu para falar-lhes assim?

Quem são eles para que me falem assim? Quem são eles para que eu lhes fale assim?

Do que o tenente-capitão fala quando se refere ao Brasil e ao povo?

É preciso pontuar de imediato que, entre os adeptos do atual governante, há seguidores que não se confundem com apoiadores. Essa diferença é essencial para observar o jogo das formações imaginárias a serem analisadas.

Os apoiadores alavancaram, com seu poder econômico, o capitão à presidência e o mantêm lá. Eles se guardam cuidadosamente à sombra. Não é de seu interesse aparecer. Apoiaram antes e continuam a apoiar agora o tenente-capitão para que execute o trabalho de desconstrução do Brasil, razão pela qual o elegeram, facultando-lhes, desse modo, apropriar-se de bens patrimoniais que pertencem a todos, assegurados pela Constituição. Eis a imagem que os apoiadores fazem do tenente-capitão: o presidente certo para fazer o serviço que dele é esperado e para o qual foi eleito.

Os apoiadores se subjetivam em uma formação discursiva de direita, inscrevendo-se em uma posição-sujeito neoliberal, através da qual se relacionam com o tenente-capitão que foi eleito para servi-los. Basta relembrar algumas declarações de eleitores entre arrependidos e constrangidos: "Era o que havia de menos pior" dizem alguns. "Era ele ou o PT", dizem outros. Essas duas formulações apontam para sua tomada de posição: são eleitores inscritos em uma posição-sujeito que odeia o PT e seus programas sociais, e oscilam entre direita e extrema direita ${ }^{3}$. Ou seja, contraidentificam-se com o (des)presidente, mas, para eles, o capitão foi o melhor caminho para eliminar as políticas sociais e privatizar tudo, da saúde à educação, estabelecendo o tão desejado Estado Mínimo.

Os seguidores, ao contrário dos apoiadores, são extremamente visíveis e ruidosos. Exibem-se vestidos de verde e amarelo, como os torcedores brasileiros durante a copa do mundo. Apropriaramse da bandeira do Brasil e a agitam, em suas manifestações, como se fosse a bandeira de seu clube. Gritam frases pré-fabricadas, cujo efeito de sentido é sempre o mesmo: "Bolsonaro, eu te amo!" "Mito!". Esses seguidores dedicam seu apoio e amor incondicionais ao seu ídolo. Atendem a suas convocações, espelham-se em sua práxis violenta, seja na mobilização da língua fascista ${ }^{4}$ como no tom de voz e atitudes, comportando-se a sua imagem e semelhança.

Trata-se de uma camada social cujas ideias estavam represadas desde o término da ditadura militar. Tais ideias correspondem ao que Laclau (2016) chama de impensabilidade e Vidal (2016) designa por mal de discurso, pois nem tudo pode ser dito em uma democracia, de modo que o

\footnotetext{
${ }^{3}$ Essa posição-sujeito também tem sido designada de ultradireita e direita radical. Aqui, será sempre nomeada como extrema direita.

${ }^{4}$ Essa noção será trabalhada na seção 2.
} 


\section{REVISTA DA ABRALIN}

impensável torna-se indizível. O impensável estabelece os limites do dizer, determinando a fronteira entre o que pode ser dito e interditando o que não deve ser enunciado.

Mas, a partir de meados da última década, essa parcela da população sentiu-se cada vez mais encorajada a pedir a volta dos militares ao poder. Começaram, quase discretamente, nas manifestações de 2013. Contudo, a partir das manifestações de 2015 (INDURSKY, 2016), perderam a inibição e passaram a implorar pela volta dos militares ao poder. Daí em diante, não hesitaram em ofender a Presidente Dilma Rousseff, como, por exemplo, em um estádio de futebol, durante a copa do mundo, mandando-a tomar no "cu". Essa camada social atua como turba, no anonimato. E, quando toma a palavra, não o faz com um discurso estruturado. Serve-se de palavras isoladas, frequentemente chulas como acabamos de observar, ou de frases curtas. Essa turba pode ser aproximada ao que Freud designou de massa:

\footnotetext{
Na massa o indivíduo é colocado sob condições que lhe permitem se livrar dos recalcamentos, de suas moções de impulso inconscientes. As qualidades aparentemente novas que ele então mostra são justamente as manifestações desse inconsciente, que, afinal, contém tudo o que há de malvado na alma humana. (FREUD, 2017 [1921], p. 44).
}

Essa camada social, que se inscreveu na cena pública a partir de 2015, desde então tem crescido. O capitão veio preencher um vazio de liderança e, assim, mais do que seu presidente, tornou-se seu ídolo. Dele trazem a língua fascista e a práxis violenta, inscrevendo-se, desse modo, em uma mesma posição-sujeito de extrema direita ${ }^{5}$, pois "...a massa se dobra com submissão diante de uma autoridade forte. Sua coragem a seduz, sua autoridade se impõe sobre ela" (LE BON, apud COURTINE, 2015, p. $283)^{6}$. Embora esses seguidores não possam ser entendidos como "massa" agem como tal. Eis a imagem que fazem de si: estão a serviço do tenente-capitão, agindo como sua tropa de choque, como se apresenta(va) o grupo "300 do Brasil": "\# fechados com Bolsonaro". Esse grupo representa a fisionomia de seus seguidores e faz ressoar/evocar uma versão caricata da juventude hitlerista.

Os seguidores, diferentemente dos apoiadores, identificam-se plenamente com seu ídolo. São os bons sujeitos de que nos fala Pêcheux (1988 [1975]). É para esses seguidores que o capitão tem tempo para parar no que se convencionou chamar de "cercadinho", sorrir, dizer algumas palavras, criticar a imprensa e atacar a oposição, enquanto esfrega o nariz e aperta algumas mãos. Não importa o que diga, sempre é apoiado de forma incondicional, aos gritos de "deixem o presidente trabalhar!". Esses seguidores agem como os crentes de seitas religiosas, movidos por uma fé cega, submetendo-se totalmente, sem hesitação. Nas palavras de Pêcheux (1988 [1975]), trata-se de uma identificação plena e, na formulação de Althusser (1970 [1967]), uma submissão sem falhas, que conduz esses seguidores a apoiar tudo que seu "mito" faz e diz. De modo que, espelhando-se no capitão, também recusam-se a usar máscara.

\footnotetext{
${ }^{5}$ Essa posição-sujeito está sendo designada provisoriamente de extrema direita, mas será repensada mais adiante, nessa mesma seção.

${ }^{6}$ A obra de LE BON, citada por Courtine - La psychologie des foules - foi publicada em 1896. O que chama a atenção é que os seguidores, aqui em observação, agem da mesma forma que a multidão, no século XIX.
} 


\section{REVISTA DA ABRALIN}

Em seu imaginário, o capitão é o Messias, sem nenhum trocadilho com seu nome, e sua palavra soa como se fosse A Palavra. Esse é o imaginário que projetam sobre si e seu ídolo.

Nesse passo, cabe uma pergunta: se há apoiadores e seguidores, há algo que pode ser designado de bolsonarismo?

A seguir, passo a examinar as formações imaginárias que sustentam as práticas discursivas do tenente-capitão e seus modos de dizer sobre seus adeptos. Tais formações são da ordem do inconsciente e irrompem no discurso, feito a ponta de um iceberg, "trazendo 'já ditos' e 'já ouvidos', através dos quais se constitui a substância das formações imaginárias" (PÊCHEUX, 2019 [1969], p. 42). Ess as formações serão tomadas no presente ensaio como um observatório do político que se materializa na língua pelo viés das relações que o sujeito estabelece com o outro. Essa é a razão de propor aqui uma escuta discursiva da fala pública do tenente-capitão, pois "a fala pública é uma dimensão constitutiva da política" e nela residem "as distintas maneiras pelas quais o homem se dirige ao homem" sendo "reveladoras das diferentes construções sociais e históricas das identidades dos homens em sociedade" (PIOVEZANI, 2015, p.291). Para tanto, serão recortadas sequências discursivas (SD) de declarações que circularam em diferentes mídias: imprensa tradicional, imprensa alternativa, TV, YouTube, redes sociais, bem como da famosa reunião ministerial de 22 de abril que, por decisão do Supremo, também tornou-se pública.

Inicio com a imagem que o (des)presidente projeta sobre seus apoiadores. Para isso, tomo uma sua declaração, em discurso proferido durante uma homenagem que lhe foi prestada por membros do agronegócio de Sinop, MT:

SD1 - Eu sou empregado de vocês, vocês são nossos patrões. A vocês nós devemos lealdade absoluta, por vocês nós lutamos. (Estado de Minas, 19.09.20)

Esse modo de dizer-se a serviço dos empresários dá a ver o jogo de formações imaginárias que sustentam seu discurso e o efeito de sentido que lhe subjaz: eles, por serem os "patrões" são os que decidem os rumos do país, suas prioridades e desenham as políticas a serem seguidas. Curiosamente, essa formação imaginária assemelha-se muito ao imaginário que seus seguidores projetam sobre o capitão-presidente. Ambas correspondem ao bom sujeito que se submete ao Sujeito, com ele identificando-se plenamente (PÊCHEUX, 1988 [1975]).

Exploremos, a seguir, o imaginário que o tenente-capitão projeta sobre seus seguidores. Para tanto, tomo uma declaração produzida na tristemente famosa reunião ministerial de 22 de abril de 2020. Ao referir-se aos seguidores, afirmou:

SD2 - O campo fértil pra aparecer...uns porcaria aí, né? levando a...aquela bandeira do...do...do povo ao meu lado, não custa nada. (YouTube, Poder360)

A devoção que lhe é dedicada por seus seguidores é respondida, como é possível constatar em SD2, com total desprezo. Hesitando nomeá-los como povo, reformula-se e os qualifica de "porcaria". 


\section{REVISTA DA ABRALIN}

E não poderia ser diferente. O "povo" a quem o tenente-capitão dedica verdadeira devoção é outro. São os donos do Brasil, os donos do capital,.que importam. Por isso titubeia em nomear seus seguidores de povo. Já o povo, esse não passa de uma "porcaria".

Pode-se ir além: quando o (des)presidente diz estar "O Brasil acima de tudo", fala de um Brasil imaginário e altamente excludente, no qual cabem apenas os que o apoiam e os que comungam de seu posicionamento ideológico. Nesse Brasil, o povo não está incluído, nem os que se lhe opõem. E, certamente, cientistas, pesquisadores, professores e a classe artística tampouco fazem parte desse Brasil. Sob a nomeação Brasil, podemos identificar industriais, empresários, banqueiros, em suma, os membros da classe privilegiada, os detentores do capital e os verdadeiros donos do Brasil, os que possuem os meios para produzir riqueza. Em suma: um Brasil alicerçado em uma ditadura do capital.

O povo está excluído desse Brasil, pois ele só causa prejuízo aos empresários, gerando gastos com salários, direitos sociais, direitos trabalhistas, férias, repouso remunerado, aposentadoria, saúde e educação públicas. Em suma, o povo "quebra os pobres empresários". Quando ainda estava na Câmara dos Deputados, explicitou o que pensa sobre o povo pobre:

SD3 - Só tem uma utilidade o pobre nesse país: votar. Título de eleitor na mão e com diploma de burro no bolso. Só pra isso, mais nada. ${ }^{7}$

Explorando o jogo cruzado desse imaginário, pode-se concluir que o povo serve, por um lado, para trabalhar, para produzir a riqueza dos donos do poder, sem dela usufruir, e, por outro lado, para mostrar aos demais brasileiros - que o capitão-presidente chama, à semelhança dos ditadores, de "maus brasileiros" - que o povo está com ele, produzindo o efeito de sentido de uma massa de seguidores pronta a atacar o Congresso e fechar o Supremo. O povo representa a força de trabalho para os donos do poder e um "curral" eleitoral para o tenente-capitão, como podemos ver, a seguir, em uma manifestação feita na Reunião Ministerial de 22.04.2020:

SD4 - Tem de ser um governo com altivez. Mostrar que nós temos o povo do nosso lado. (YouTube, Poder 360

Ao que tudo indica, nada mudou em nossa formação social no que diz respeito ao trabalhador: ela é extremamente conservadora e autoritária, onde ressoam saberes escravocratas e fascistas.

Assim, tanto os seguidores quanto o tenente-capitão colocam-se em posição subalterna frente a seus ídolos. E seus ídolos, por sua vez, o desprezam solenemente. Essa é a formação imaginária que preside à práxis discursiva do capitão sobre seus apoiadores e seguidores.

Vejamos, a seguir, as formações imaginárias do tenente-capitão sobre o capitão-presidente. Esse imaginário é também bastante revelador. Frequentemente ele necessita reafirmar-se e o faz quase gritando:

\footnotetext{
${ }^{7}$ https://youtu.be/WDA6_rzNhSs Acesso 20.09.2020.
} 


\section{REVISTA DA ABRALIN}

SD5 - Eu sou o presidente! Sou eu que mando aqui, pô! (Estadão, 23.06.20) ${ }^{8}$

SD6 - Eu sou o chefe supremo das Forças Armadas. Ponto final. (YouTube, Poder360)

Seu tom de voz é sempre duro, áspero, beligerante e representa a voz de comando que, em seu imaginário, remete ao ditador que deseja ser. Aparentemente espelha-se na entonação e expressão facial bem como no olhar igualmente duro de Hitler e Mussolini que são, ao que tudo leva a crer, seus modelos políticos. No que tange à entonação que o (des)presidente assume, trago uma formulação dos estudos de Pedro de Souza sobre a voz: "dicção (modo de dizer) e voz (modo de ouvir) situam-se no mesmo nível e mutuamente se imbricam" (SOUZA, p.203). Penso ser a entonação que o capitão assume em suas falas públicas traço essencial de seu modo de subjetivação em uma FD de direita, inscrevendo-se em uma posição-sujeito fascista ${ }^{9}$.

Vejamos mais uma manifestação discursiva, produzida frente aos seguidores que carregavam cartazes pedindo a volta do AI-5, o fechamento do Congresso e do STF:

SD7 - Não queremos negociar nada! Queremos ação pelo Brasil! Chega da velha política! Agora é Brasil acima de tudo e Deus acima de todos! (FSP, 19.04.20) ${ }^{10}$

Além do tom duro e beligerante, percebe-se sua adesão às demandas dos manifestantes. Posteriormente, ao ser cobrado pelo apoio dado com sua presença a uma manifestação nitidamente anticonstitucional, respondeu:

SD8 - Não sou contra a Constituição, ao contrário. Eu sou, realmente, a Constituição! (FSP, 20.04.20)

Essa autodefinição, que faz ressoar o enunciado "L'État c'est moi" ( O Estado sou eu), atribuído a Louis XIV, expõe seu perfil autoritário, que flerta constante e abertamente com a ditadura.

Essa formação imaginária permite questionar: seria isso, então, o que chamam de bolsonarismo? Um governo que se identifica com o fascismo e sonha com a volta da ditadura, com o (des)presidente na posição de ditador?

Se assim é, diria que o efeito de sentido que esse imaginário projeta é o de alguém muito ressentido com o exército que o reformou após sua tentativa terrorista, pois "o ressentimento designa um afeto associado a formas de agressividade, raiva [...], provocando desejos de vingança [...]" (ANSART-DOURLEN, 2001, p.351). Ressentimento esse que, no caso do tenente-capitão, é materializado ao dizer que a ditadura errou ao não matar uns 30.000 , deixando implícito que seria um ditador

\footnotetext{
${ }^{8}$ O jornal Estado de São Paulo será referenciado como Estadão.

${ }^{9}$ Estou retomando nesse ponto o que apontei mais acima, nessa mesma seção, como uma posição-sujeito de extrema direita. Reformulo, agora com mais propriedade: o (des)presidente se subjetiva, não em uma posição-sujeito de extrema direita, mas em uma posição ainda mais radical, a fascista, no interior da FD de direita.

${ }^{10}$ O jornal Folha de São Paulo será referenciado como FSP.
} 


\section{REVISTA DA ABRALIN}

corajoso e eficiente, e faria o que os ditadores não tiveram a coragem de fazer. Esse imaginário também permite perceber que o tenente-capitão teve seu sonho de tornar-se ditador frustrado com sua expulsão do exército e o término da ditadura, razão pela qual tenta constantemente estimular seus seguidores a pedir o AI-5 ou fechar o Congresso, como pudemos constatar com a simulação de ataque ao Supremo, com fogos de artifício estourando sobre o prédio. Esse desejo é expresso claramente na reunião ministerial de abril:

SD9 - Olha eu tô... como é fácil impor uma ditadura no Brasil. Como é fácil. O povo tá dentro de casa. Por isso que eu quero, Ministro da Justiça e Ministro da Defesa, que o povo se arme! (YouTube, Poder360)

Seria então o bolsonarismo a nova versão do fascismo à brasileira?

\section{A memória discursiva do fascismo e sua atualização}

Há uma memória discursiva proveniente da Formação Discursiva nazifascista que se atualizou em determinados momentos históricos do Brasil. Foi assim com o integralismo, versão brasileira do fascismo e contemporânea do regime fascista de Mussolini e do III Reich de Hitler, sem contar com o Estado Novo de Getúlio Vargas, que também flertou à luz do dia com esses regimes. Anos depois, foi a vez da ditadura militar beber nessa mesma fonte. Como é possível perceber, nossa formação social é frequentemente atravessada por saberes e práticas autoritárias. E assim chegamos ao (des)governo do tenente-capitão e suas arremetidas nessa mesma direção.

É preciso, entretanto, lembrar que o capitão não empolgou o poder. Nem, tampouco, houve uma quartelada. Ele chegou ao poder através dos instrumentos democráticos e foi como presidente eleito que tomou posse. No entanto, já como presidente, aproveita-se da liberdade de expressão, própria da democracia e suas instituições, para atacá-la e corroê-la, atentando constantemente contra o Estado de Direito.

Se assim é, seria o regime em que vivemos hoje uma espécie de "democracia iliberal ${ }^{11 "}$, para usar a designação cunhada por Orbán, primeiro ministro da Hungria? E ainda: uma democracia iliberal confunde-se com um regime fascista?

No quadro teórico da Análise do Discurso (AD), parte-se do fato de que os saberes estão inscritos em formações discursivas (FD) e representam o ideológico próprio da formação social de uma sociedade. E o sujeito, ao tomar a palavra, o faz a partir de uma posição-sujeito inscrita em uma

\footnotetext{
11 A filósofa húngara Ágnes Heller relata que Orbán, primeiro ministro da Hungria, estabeleceu uma nova forma de tirania que denominou de democracia iliberal. "Democracia, pois o regime é fruto de uma votação majoritária. 'Iliberal' porque não há mais direitos humanos, nem pluralismo. É um governo totalmente centralizado; nada mais pode acontecer na Hungria sem que ele assim tenha querido". Entrevista concedida pela filósofa à Sarah Halifa-Legrand, Le Nouvel Observateur, 15.12.2018.
} 


\section{REVISTA DA ABRALIN}

determinada FD com a qual se identifica. Assim, ao materializar através da língua sua tomada de posição, o sujeito do discurso se subjetiva.

Com isso em mente, vou proceder a uma escuta discursiva de falas públicas do tenente-capitão e analisar suas tomadas de posição com as lentes que o dispositivo teórico da AD disponibiliza. Para tanto, remonto inicialmente a um período anterior à presidência, quando ainda era um deputado bastante medíocre. Em uma entrevista de 1999, declarou:

SD10 - "Sou favorável ao pau de arara, à tortura". "Chegando à Presidência, daria um golpe e fecharia o Congresso no mesmo dia". "Na ditadura só desapareceram 282, a maioria, marginais". "Através do voto, não vamos mudar nada. Só quando partirmos para uma guerra civil, e fazendo o trabalho que o regime militar não fez, matando uns 30.000, começando por FHC. Vai morrer alguns inocentes? Tudo bem. ${ }^{12}$

Essa era a tomada de posição do tenente-capitão quando era deputado. Passo, agora, a observar a tomada de posição do capitão-presidente. Algo teria mudado de 1999 aos nossos dias?

Há algo muito peculiar que se depreende do modo como o (des)presidente se subjetiva na língua. Em função disso, passo a observar seus modos de dizer e a língua que pratica, agora a partir do lugar discursivo de presidente ${ }^{13}$, salientando, inicialmente, que lugar discursivo não se confunde com posição-sujeito. O lugar discursivo consiste em um espaço sempre-já-lá, ainda não afetado por uma Formação Discursiva, onde circulam discursos dispersos, próprios àquele lugar (DALTOÉ, 2011). E, no caso aqui em tela, trata-se de um lugar discursivo específico, o de presidente, no qual se pratica uma língua política que remete a "um dizer produzido no exercício do poder" (ZOPPI-FONTANA, 2011, p. 69).

Esta observação será guiada por uma interrogação: os modos de dizer do capitão-presidente são adequados ao lugar discursivo de presidente, inscrito em um regime democrático? E que efeitos de sentido produzem? Tomemos as SD que seguem, à luz desse questionamento.

Sobre as recomendações para prevenir-se da COVID, declarou:

$$
\text { SD11 - Ficar em casa é coisa de covarde. (Twitter, 25.03.20) }
$$

Em suas manifestações discursivas, com frequência refere-se a atitudes covardes do outro, aquele que dele diverge ou que o questiona. A coragem parece ser uma qualidade que procura projetar sobre sua imagem. Coragem, em seu discurso, produz o efeito de sentido de que não teme o perigo. E, em contraponto, ao referir-se aos jornalistas que teriam desqualificado seu pretendido histórico de atleta,

\footnotetext{
${ }^{12}$ Vídeo YouTube, Acesso em 12.09.2020.

${ }^{13}$ A noção lugar discursivo foi formulada, em 2004, por Evandra Grigoletto, em sua tese O discurso de divulgação científica: um espaço intervalar. Foi retomada, em 2005, por Elizabeth Fontoura Dornelles em sua tese A dispersão do sujeito em lugares discursivos marcados. Andréia Daltoé, em 2011, retomou a formulação de Grigoletto, reformulando-a em função do objeto de sua tese, As metáforas de Lula: a deriva dos sentidos na língua política. Neste ensaio, retomo essa noção com base nas formulações de Daltoé (2011, p.69-73).
} 


\section{REVISTA DA ABRALIN}

chama-os de "bundões"114. Ou seja: trata-se de um atleta corajoso que enfrenta os "bundões" covardes. Questionado sobre depósitos feitos por Queiróz na conta de sua mulher, respondeu:

SD12 - Vontade de encher a tua boca com porrada, tá? Seu safado! (YouTube, 23.08.20)

À pergunta de um jornalista sobre empréstimo feito a Queiróz, retrucou:

SD13 - Pergunta pra sua mãe o comprovante que ela deu pro teu pai, tá certo? (Vídeo, Face, 20.12.19) ${ }^{15}$

A outro repórter que questionava sobre acusações contra Queiróz, disse:

SD14 - Você tem uma cara de homossexual terrível, mas nem por isso eu te acuso de ser homossexual. Se bem que não é crime ser homossexual. (G1.Globo, Vídeo, 20.12.19)

Esse conjunto de sequências discursivas (SD11 a SD14) estão em relação de paráfrase discursiva, projetando, como efeito de sentido, o que o (des)presidente entende por coragem: ser corajoso implica poder falar duro com seu inimigo, ter o direito de ofendê-lo, não respeitá-lo, e de expressar seu ódio e preconceitos.

Enquanto era deputado, subjetivava-se em uma FD de direita, inscrevendo-se em uma posiçãosujeito fascista, ao retomar, defender e identificar-se com práticas da ditadura. Foram tais repetições que me fizeram afirmar, em trabalhos anteriores (INDURSKY, 2016; 2019a, 2019b), que o capitão pratica uma língua fascista, pois ela vem carregada daquela memória, com vimos anteriormente, em SD10.

Agora, já no lugar discursivo de presidente, além de manter-se na mesma posição-sujeito, inscrevendo seu discurso na ordem da repetibilidade (INDURSKY, 2011), sua língua fascista ganhou novas nuances, assumindo uma incontinência verbal, como as sequências discursivas acima (SD11 a SD14) evidenciam: seja pelo emprego de palavrões, seja pela violência verbal, seja ainda por trazer marcas explícitas de homofobia e misoginia. Agora, não se limita mais a repetir os mesmos bordões prediletos: torturar, matar etc. Em seu atual lugar discursivo, ao subjetivar-se em sua bruta língua fascista, ultrapassa todos os limites da civilidade e torna-se grosseiro, truculento e violento, ofendendo e agredindo a quem ousar questioná-lo. Assim procedendo, o "impensável" de que nos fala Laclau, como sinalizei na primeira seção deste ensaio, tornou-se o modo de dizer que a língua política assumiu na fala pública do capitão-presidente. Klemperer, referindo-se à língua do III Reich, pontua que "As palavras podem ser como minúsculas doses de arsênico" (Klemperer, 1996, p.40). ${ }^{16}$ As palavras dessas sequências discursivas estão carregadas de afeto, elas destilam ódio, desprezo e

\footnotetext{
${ }^{14}$ O Globo, 24.08.2020.

${ }^{15}$ O Facebook será referenciado como Face.

${ }^{16}$ A tradução de "Les mots peuvent être comme de miniscules doses d'arsenic" é da autora.
} 


\section{REVISTA DA ABRALIN}

raiva, rompendo com o princípio ético da aceitabilidade que o lugar discursivo de presidente pressupõe, deixando explícitas as marcas do que estou designando de língua fascista. Vale dizer: não se trata mais de uma memória atualizada pelo discurso, como ocorria quando era deputado. Agora, no lugar discursivo de presidente, a língua fascista apresenta marcas de sua efetiva presença e atualidade. Dizendo de outro modo: a língua política com que o capitão-presidente exerce o poder é uma língua fascista.

Como o capitão-presidente não pode mandar "prender e arrebentar", pratica imaginariamente tais atos pelo viés dessa língua na qual se subjetiva. É, pois, pela língua fascista - desabrida, grosseira e chula - que ele realiza seu desejo de torturar o outro, seu inimigo. Ao dizer ao jornalista que quer "encher sua boca de porrada", em seu imaginário, está efetivamente quebrando a cara do jornalista. E assim, imaginariamente, pratica a tortura que tanto o excita. E, ao mesmo tempo, tortura todo aquele que, por azar, venha a escutar o que ele esbraveja. Através dessa língua fascista, em seu delírio, produz um simulacro de ditadura e experimenta o prazer perverso do torturador, equiparandose ao seu ídolo, o coronel torturador Ustra (INDURSKY, 2019a), pois

\footnotetext{
O perverso goza com a angústia que provoca. Há aí uma atuação [...]. Se o sintoma é uma formação inconsciente, o ato perverso é a sua perversão [...]. O ato perverso é o avesso do sintoma, pois faz com que ecloda a angústia no outro. [...]. O perverso atua como forma de gozar [...]. (MALISKA, 2017, p.84-50).
}

A perversão do capitão-presidente está na origem do mal-estar social vigente hoje em parte substantiva do corpo social. Diria, então, que o (des)presidente, de certa forma, atinge seu gozo, pois, "o gozo não é a satisfação (dada pelo limite) nem o prazer (dado pela experiência corpórea), mas a passagem do prazer-satisfação pelo campo do Outro" (DUNKER, 2020). Só assim é possível interpretar suas ameaças, seu destempero, sua língua desabrida.

Observemos, a seguir, a forma linguística de suas manifestações discursivas.

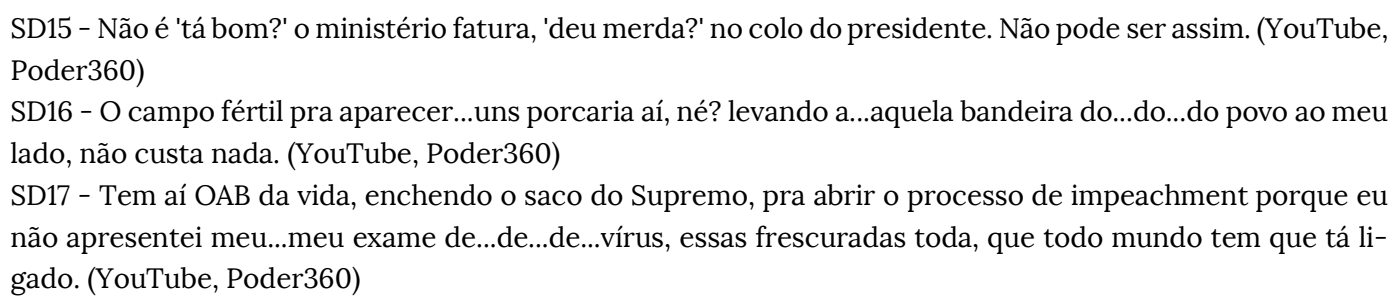

As sequências discursivas acima (SD15 a SD17) foram recortadas da Reunião Ministerial de 22 de abril de 2020. Tomo-as para observar sua estruturação linguística. A partir delas, percebe-se, além do uso de um léxico chulo e grosseiro, pouco adequado para um presidente se pronunciar em uma Reunião Ministerial, o emprego de uma fraseologia rudimentar, cuja sintaxe é pobre e desconexa. Salta aos 


\section{REVISTA DA ABRALIN}

olhos uma falta de decoro total: na expressão, no tom de voz beligerante ${ }^{17}$, nas palavras brutas, na falta de respeito. Sua língua fascista desfigura o lugar discursivo de um presidente democrata.

Aqui cabe um contraponto entre os generais ditadores e o capitão-presidente. Os ditadores praticavam uma língua padrão e tinham um projeto de desenvolvimento para o Brasil. Já ao capitão falta-lhe cultura e conhecimento, além de praticar uma língua pobre, desestruturada, de frases curtas e truncadas. Diria que sua língua fascista funciona como uma metáfora de seu projeto de desmonte do Brasil: da mesma forma que tritura a língua portuguesa, promove a liquidação do País.

Para sustentar o que estou afirmando, tomo um único ponto: a criação da Pós-Graduação no Brasil. Esse, que é o mais alto nível da educação superior brasileira, foi instituído na década de 60 do século passado, em plena ditadura militar! Já no atual (des)governo, a meta é destruir as Universidades Federais e, juntamente com elas, a Pós-Graduação e a pesquisa científica, pois, sabidamente, parte substantiva da pesquisa no Brasil é desenvolvida nas Universidades Públicas.

Esse contraponto põe em evidência que a admiração do tenente-capitão pela ditadura diz respeito apenas à violência de Estado por ela praticada. De resto, coloca-se na contramão do projeto desenvolvimentista dos ditadores, deixando claro seu pertencimento ao baixo clero militar.

Althusser nos lembra que "a História é certamente um 'processo sem Sujeito nem Fim(s)". (ALTHUSSER, 1978 [1973], p.71). Com base nessa premissa althusseriana, reformulo mais uma vez a pergunta que venho fazendo ao longo deste artigo: se o tenente-capitão é fascista, como vimos acima, isso implica vivermos hoje em um regime fascista?

Há historiadores e cientistas políticos que entendem ser o nazismo e o fascismo regimes datados. Há outros que defendem ser possível tais movimentos ressurgirem. Há, ainda, quem diga que, hoje, o que vemos se alastrar, não só no Brasil, mas também nos EUA e na Europa, seja o que designam de neofascismo, o qual sinaliza um sintoma da crise que o capitalismo atravessa, nas atuais condições de produção neoliberais, que são fortemente autoritárias. Não pretendo entrar nessa discussão, mas vou procurar pensar, à luz da $\mathrm{AD}$, o que significa a presença desses fantasmas do fascismo que insistem em se materializar nas práticas discursivas do (des)presidente.

Como sabemos, os sentidos deslizam de uma FD para outra, pois suas fronteiras são porosas. E os saberes, ao deslizarem, trazem consigo pré-construídos carregados de um determinado espaço de memória. Quando esses saberes nazifascistas são atualizados, entendo que eles se inscrevem em uma FD de direita e em uma posição-sujeito fascista. Isso significa, vale sublinhar, que a FD de direita é extremamente heterogênea, pois há saberes nela inscritos provenientes de diferentes regiões do interdiscurso. Essa heterogeneidade indica que a forma-sujeito que organiza essa FD se fragmentou em várias posições-sujeito (INDURSKY, 2008), entre elas, uma posição-sujeito de extrema direita, na qual se inscrevem os defensores do neoliberalismo, que defendem privatizações, reformas previdenciárias e trabalhistas, respeitando, entretanto, as Instituições. Ou seja, tais reformas, embora não

\footnotetext{
${ }^{17}$ Na seção 1, a entonação foi examinada, a partir de SD5 e SD6, como um traço constitutivo da subjetivação do sujeito na língua. Por essa razão, essa reflexão não é retomada aqui. No entanto, saliento que tanto a entonação quanto a expressão fisionômica e do olhar, em manifestações ao vivo e/ou gravadas em vídeo, são igualmente constitutivas da identificação do sujeito com a língua. E, no caso aqui em análise, com a língua fascista.
} 


\section{REVISTA DA ABRALIN}

sejam consensuais, não são feitas ao arrepio da Lei. Por outro lado, também há, nessa FD de direita, uma posição-sujeito fascista, com a qual se identificam os que defendem a ditadura, a eliminação das Instituições, a censura, a tortura, a morte e onde o Estado de Direito passa ao largo. Com base nessa distinção, pode-se afirmar que nem todo sujeito que se identifica com uma posição-sujeito de extrema direita é fascista, embora ambas se aproximem em muitos aspectos, podendo mesmo estabelecer alianças entre si. Entendo que é uma aliança dessas duas posições-sujeito que sustenta o atual governo.

Vejamos como a posição-sujeito fascista se projeta no discurso do atual governo brasileiro. Como veremos, não há como dizer que os saberes que, através do discurso do (des)presidente, se materializam sejam idênticos aos saberes fascistas, pois a conjuntura em que se produzem determina transformações e o discurso, na tensão entre o mesmo e o diferente, produz deslizamentos de sentido. No entanto, a presença do fantasma do fascismo é claramente perceptível.

O fascismo institui um inimigo a combater e eliminar, seja ele real ou imaginário. No nazismo, judeus, ciganos, homossexuais foram instituídos como o inimigo a eliminar. Em função disso, foram perseguidos, jogados em campos de concentração, reduzidos a escravos e mortos, em nome da raça pura. No Estado Novo, os inimigos eram os comunistas que também foram perseguidos e encarcerados, mas a prática da eugenia não presidia essas ações. Na ditadura militar, o inimigo também era o comunismo e os comunistas eram presos, torturados, mortos e seus corpos, não raramente, desaparecidos.

No Brasil atual, o capitão-presidente também elegeu seus inimigos: a esquerda em geral e o PT, de forma específica, a imprensa, a educação e a ciência. A "limpeza eugênica" se transforma em uma "limpeza ideológica". Mas não só. Esse governo é movido por muitos ódios: ódio à cultura, ódio à educação, ódio à ciência e aos cientistas, ódio à pesquisa, ódio ao ensino público. Esses são os inimigos constituídos a serem combatidos e eliminados.

Cabe, então, a pergunta: o atual governo, sob a presidência do tenente-capitão, também exerce esse poder ilimitado sobre os corpos de seus cidadãos?

No presente, não há órgãos de repressão e tortura como durante a ditadura. Não pelo menos oficialmente. Mas o tenente-capitão estabeleceu forte aliança com a polícia e as milícias. Em função disso, os "porões da ditadura" não se fazem mais necessários. O aprendizado da ditadura foi absorvido e transformado. Agora, essas forças paralelas vão diretamente ao final e matam os desafetos e os adversários, enquanto mandantes não são identificados nem julgados. Como disse o tenente-capitão, quando ainda era um deputado obscuro: "o erro da ditadura foi ter torturado e não matado". E assim, a milícia está armada e revestida do direito de matar e de ficar impune, aproximando-se do que Mbembe (2018) chama de necropolítica. Ninguém é preso, a polícia investiga por anos e anos, mas não chega ao mandante dos crimes. De modo que gritos como "quem matou Marielle?", por exemplo, continuam ressoando, mas acabam por cair no vácuo, como foi o caso de Amarildo, que o manto do esquecimento praticamente já encobriu. Então, há, sim, uma nova forma de eugenia, praticada sem campos de extermínio e cujos alvos são os moradores das favelas, os negros, os indígenas. $\mathrm{E}$, dessa forma, as práticas do governo se apresentam bastante similares às do fascismo. 


\section{REVISTA DA ABRALIN}

Quanto aos políticos de esquerda, esses são objeto de uma "limpeza ideológica" e, mais uma vez, soa por traz dessa limpeza, o desejo do tenente-capitão, quando ainda era pré-candidato: 'Vamos metralhar a petralhada toda!". Como podemos ver, o Estado Brasileiro, sob a presidência do tenentecapitão, também exerce poder sobre os corpos de seus cidadãos, embora sem os poderes absolutos de que os regimes totalitários costumam gozar.

A censura é outra marca desses regimes. E ela impedia que seus crimes fossem denunciados pela imprensa. No momento atual, a imprensa, com raras exceções, não está sob censura, embora seja continuamente atacada pelo capitão-presidente. E é através da imprensa que tomamos conhecimento das investidas contra as liberdades e as Instituições.

Os regimes autoritários sempre contaram com seus apoiadores entre os brasileiros que concordavam com suas práticas. No Estado Novo, Getúlio reunia uma massa de trabalhadores para seus comícios, pois ele introduziu leis trabalhistas que os protegeram, sendo por eles chamado de pai do povo. A ditadura militar também tinha sua massa de apoiadores: o povo brasileiro, que temia o comunismo e as reformas de base que a esquerda defendia. Os generais da ditadura tinham seus seguidores e discursavam através das telas de TV, reunidas em cadeia nacional. E, dessa forma, penetravam em todas as casas, convenientemente às $20 \mathrm{~h}$, quando os brasileiros estavam reunidos na sala de jantar, como os Mutantes cantaram, e aguardavam a novela das $8 \mathrm{~h}$. Já o atual (des)presidente fala com seus seguidores através das redes sociais e essas manifestações são repercutidas por eles. Difícil de mesurar, entretanto, seu real alcance. Poderíamos entendê-los como uma massa não visível?

De tudo quanto precede, percebe-se que o nazifascismo fascina o capitão. Esse fascínio se mostra na apropriação do discurso fascista, seja tomando de empréstimo o lema nazista, seja publicando uma frase famosa de Mussolini em sua página no Facebook, um dia após os protestos antifascistas "melhor viver um dia de leão do que cem anos de cordeiro". Ou, ainda, atualizando em seu discurso práticas da ditadura militar de quem ele é descendente e admirador, a um só tempo saudoso e ressentido. Também sua língua fascista, desabrida, chula e tosca, marca sua identificação com esses regimes, como verificamos pela observação de seus modos de dizer. Entretanto, as Instituições, embora por vezes se mostrem muito fragilizadas e até certo ponto submissas, ainda reagem às investidas mais graves do capitão-presidente, desarticulando suas tentativas de autogolpe.

De tudo quanto precede, parece lícito pensar que não vivemos, pelo menos ainda, em uma ditadura; que a liberdade de expressão, apesar das frequentes investidas contra ela, ainda existe. Por conseguinte, também não vivemos em uma democracia iliberal. No entanto, observando as práticas discursivas do tenente-capitão, podemos perceber que, apesar dos intervalos de relativa democracia, vivemos fundamentalmente em uma sociedade conservadora e plantada no autoritarismo, traços esses que se materializam em seu discurso. As classes dominantes ainda estão presas a uma mentalidade escravocrata. São esses traços de nossa formação social que possibilitam a materialização e capilarização de saberes fascistas no discurso político ora em circulação no Brasil. Isso, entretanto, não transforma de pronto o Estado brasileiro em um Estado Fascista. No entanto, é impossível ignorar os fortes avanços nessa direção. 


\section{REVISTA DA ABRALIN}

O capitão-presidente não é um ditador nem governa sozinho, embora perceba-se como o presidente de uma ditadura. Trouxe para dentro do governo um sem-número de militares, saudosos da ditadura, inscrevendo-se, todos, em uma posição-sujeito negacionista: denegam constantemente os crimes praticados durante o período ditatorial, trabalhando, desse modo, na manutenção de uma política do esquecimento (INDURSKY, 2013). Essa é a dimensão do real que afeta a língua: o impossível de dizer que é encoberto pelo esquecimento. Sobre a natureza desse real, Milner, refletindo sobre o Holocausto, afirma:

Existe algo real com o que os nomes colidem ou que os excede [...]. Essas memórias entretecidas têm exatamente a consistência de fantasma. Mas se existe o esquecimento, então há outra coisa além do fantasma da memória: tem havido um real, como acontecimento singular e contingente, o qual faz signo ao sujeito na forma de esquecimento (MILNER, 2017 [1988], p.84).

Mas, se o real da língua é o impossível de dizer e afeta o discurso dos militares que defendem a ditadura militar, interditando a simbolização dos acontecimentos terríveis ocorridos nos porões da ditadura, por outro lado, o real também atravessa as práticas discursivas do capitão, porém às avessas, indicando que, para ele, é impossível dizer de outro modo. Lembremos como Gadet e Pêcheux iluminam a quebra desse interdito: "Baseando-nos contraditoriamente nessa tese de Milner [do real da língua], tentamos aqui fazer trabalhar o real da história como uma contradição da qual o impossível não seria foracluído" (GADET; PÊCHEUX, 2004 [1981], p.52). Vale dizer: é o real da história que autoriza simbolizar o que o real da língua interdita. Assim, o tenente-capitão materializa os fantasmas da ditadura, dizendo sobre os crimes nela praticados, como vimos mais acima, na SD10, na qual se refere explicitamente às mortes e à tortura praticadas durante aquele período sombrio. Essa é a contradição que o desencontro do real da língua com o real da história expõe.

Esses fantasmas, como vimos, povoam o teatro grotesco em que esse (des)governo atua. Desloco, então, meu observatório para essa instância.

\section{Os (des)ministros, a montagem do teatro do grotesco e a desconstrução do Brasil}

Marx, em O 18 brumário de Luís Bonaparte, retoma uma afirmação de Hegel - "todos os grandes fatos e todos os grandes personagens da história mundial são encenados, por assim dizer, duas vezes" - e comenta: "Ele se esqueceu de acrescentar: a primeira vez como tragédia, a segunda como farsa" (MARX, 2011 [1852], p.25). 


\section{REVISTA DA ABRALIN}

Como pontuei na introdução deste ensaio, entendo que o cenário político brasileiro não mais corresponde a uma farsa. Agora, vivemos um teatro do grotesco. E o (des)presidente não está só em suas performances. Seus ministros não são meros coadjuvantes. Bem ao contrário. Eles protagonizam papéis importantes no teatro do grotesco encenado pelo (des)governo. Assim, vou desenvolver um pouco mais a metáfora do teatro e dividi-la em quatro atos.

O primeiro ato tem lugar no Ministério da Educação e é desempenhado por seus sucessivos (des)ministros que têm colaborado fortemente para a encenação do grotesco. Nesse Ministério, vou focar apenas na Educação Superior, embora os demais níveis de ensino também estão sendo sucateados.

Detenho-me, inicialmente, no terceiro (des)ministro, Abraham Weintraub, que gostava de dançar com um guarda-chuva, à Gene Kelly, enquanto dizia "gracinhas". Caricaturou os chineses, fabulando um "plano cebolinha para dominar o mundo" e, com isso, armou um incidente internacional com um dos maiores importadores de carne do Brasil. Em um twitter, comparou a operação da Polícia Federal, em 27.05.20, no âmbito do inquérito das fake news, à ação da polícia política nazista, comparando-a à Noite dos Cristais e, com isso, desencadeou protestos da comunidade judaica do Brasil, bem como do embaixador israelense, Estado com o qual o (des)governo mantém "boas" relações, em função de seus apoiadores neopentecostais e de seu Israel bíblico e imaginário. Estabeleceu enfrentamento com as Universidades Federais ao afirmar que os estudantes universitários fazem orgias, plantam e fumam maconha enquanto correm nus pelos campi, apenas produzindo balbúrdia, sem retorno algum ao Estado. Desse modo, expôs as intenções privatistas do (des)governo. Em função de tais alegações, anunciou corte de bolsas e contingenciamento do orçamento das universidades. E, novamente, desencadeou protestos, dessa vez por parte das autoridades universitárias. Assim, sua "produção" ministerial foi bastante significativa para o teatro do grotesco. Por fim, caiu em função da declaração feita na reunião ministerial de abril: "Por mim, botava esses vagabundos todos na cadeia. Começando no STF".

Qual a função desse teatro grotesco para a Educação?

Inicio com uma declaração do primeiro (des)ministro da Educação, Ricardo Vélez Rodrigues:

SD18 - A ideia de Universidade para todos não existe. As universidades devem ficar reservadas para uma elite intelectual. (Valor Econômico, 28.01.19)

A essa declaração, somam-se duas outras, dessa vez, por co-adjuvantes externos à pasta. A primeira delas (SD19) foi enunciada pelo (des)ministro da Economia, Paulo Guedes e a segunda (SD20), pelo vice-presidente, General Mourão:

SD19 - O livro é um produto de elite, logo, quem compra pode pagar um preço maior. (Correio Brasiliense, 20.10.20)

SD20 - É 'um paradoxo' no Brasil o atendimento educacional nas universidades federais para gente que poderia pagar os seus custos e está recebendo um ensino de graça, posteriormente não devolvendo nada para o País. (Agência Estado, 26.08.20) 


\section{REVISTA DA ABRALIN}

Assim, desde os primeiros dias e atravessando diferentes setores do governo, estava explicitado o projeto de privatização da Educação Superior no Brasil. Para tanto, iniciaram por cortar os recursos destinados à Educação, de modo geral, e à Pós-Graduação de modo específico.

Uma das consequências desse desmonte da Educação é a liquidação da pesquisa no Brasil, num movimento anti-científico que denega a produção da comunidade acadêmica e desperdiça o conhecimento acumulado pelos cientistas brasileiros. O efeito dessa política predatória é a fuga de cérebros e importação de tudo: conhecimento, tecnologia, produtos, equipamentos, medicamentos, insumos. Ou seja: submissão plena, perda da autonomia e alto custo. O Brasil voltando a importar tudo, como sucedia no passado. Em suma: um Brasil de joelhos.

No entanto, não é possível creditar essa guerra às universidades e à pesquisa bem como o negacionismo a tudo que é científico exclusivamente ao fascismo. Com certeza, o fascismo se faz presente nessa desconstrução da Educação, mas a ele está associada uma outra variável: a forma atual do capitalismo, em sua modalidade neoliberal. Um capitalismo que visa exclusivamente à acumulação do lucro, sem considerar o social. O sucateamento das Universidades implica a mercantilização da Educação e sua entrega às mãos da iniciativa privada que não tem nenhum compromisso além do lucro. Além disso, não é difícil de antecipar que o corpo docente das Universidades públicas será precarizado, que os currículos serão empobrecidos, atendendo aos interesses dos empresários, que a pesquisa será descontinuada para dar ênfase à sala de aula, que as áreas humanas serão sacrificadas por serem consideradas perigosas e pouco rentáveis e o acesso à Universidade ficará restrito aos que podem pagar.

O segundo ato desse teatro do grotesco se desloca para a Cultura, parente próxima da Educação. A Cultura nesse (des)governo não merece crédito algum. De início, perdeu seu estatuto de Ministério, ficando reduzida a uma Secretaria vinculada ao Ministério do Turismo. Além disso, o (des)governo foi além e deu-lhe um duro golpe ao acabar com a Lei Rouanet, substituindo-a pela Lei de Incentivo à Cultura que incentiva apenas no nome. Essa pasta não fugiu à regra e teve muitos secretários, dentre os quais vou me deter apenas no terceiro, o dramaturgo conservador Roberto Alvim, que se envolveu em polêmicas com a classe artística, atacou a grande dama do teatro brasileiro, Fernanda Montenegro, chamando-a de bruxa. Investiu contra a classe artística, ao declarar:

SD21 - Eu luto pela preservação dos princípios, valores e conquistas da civilização judaico-cristã, contra o satânico progressismo cultural. (O Globo, 24.07.19)

Por fim, foi demitido após enorme polêmica causada por um vídeo em que se apropriou de passagens inteiras de um discurso de Goebbels, responsável pela propaganda do III Reich, numa clara demonstração de admiração dos saberes nazistas, utilizando-se da pasta da Cultura para fazer propaganda fascista em nome do (des)governo.

O que subjaz a esse esforço em atacar e destruir a Cultura?

A arte e demais áreas que se vinculam à Cultura - História, Filosofia, Antropologia, Sociologia, Literatura - analisam nossa sociedade, trazendo à tona aspectos menos evidentes, que permitem 


\section{REVISTA DA ABRALIN}

entender nossa formação social e iluminar nosso presente. Essas áreas fazem pensar e a reflexão crítica, na atual conjuntura brasileira, não é vista com bons olhos. Não por acaso, o ex-secretário Alvim afirmou que lutava "contra o satânico progressismo cultural". Esta pasta escancara o desprezo e o desapreço pela Cultura e pelas ciências humanas em geral.

O terceiro ato se desenrola no Ministério da Saúde e sua colaboração para o teatro do grotesco, como veremos, é muito significativa. Nele atuaram inicialmente dois ministros, ambos médicos que, por não concordarem com a "prescrição medicamentosa" feita pelo capitão, caíram. Então, um general não-médico foi convocado, mostrando-se obedientemente inoperante frente à pandemia, tendo mesmo afirmado que, ao ser chamado para essa missão, "Não sabia nem o que é o SUS"18.

No quesito saúde pública, em tempos de pandemia, o capitão-presidente também teve seu papel assegurado no teatro do grotesco, como diversas manifestações discursivas suas dão a ver:

SD22 - Alguns vão morrer? Vão, ué, lamento. Essa é a vida. ${ }^{19}$

SD23 - E daí? Lamento. Quer que faça o quê? Eu sou Messias, mas não faço milagre. (G1.Globo.com, 28.04.20) SD24 - Temos que ter coragem de enfrentar o vírus. Tá morrendo gente? Tá! Lamento? Lamento. Mas vai morrer muito, muito, mas muito mais se a economia continuar a ser destroçada por essas medidas. (OGlobo.globo.com, 14.05.20)

Essas sequências discursivas (SD22 a SD24) mostram sua incapacidade de solidarizar-se com a dor do outro, de colocar-se no lugar daqueles que não puderam despedir-se de seus queridos e fazem ressoar outras palavras, igualmente suas, quando ainda era deputado: "Sou Capitão do Exército, minha especialidade é matar" ${ }^{20}$. Sinalizam também um dos pontos de discórdia com as medidas de confinamento social adotadas pelo Ministro Mandetta, deixando às claras que sua prioridade é a economia. Assim, entre a vida do povo trabalhador e a economia, é preciso salvar os CNPJ e o lucro dos donos do capital, numa clara sinalização de quanto o trabalhador é descartável para esse (des)presidente: morre um, muitos outros, desempregados, estão a postos para preencher a vaga no dia seguinte. E, desse modo, percebe-se, mais uma vez, que, nesse teatro do grotesco, a Saúde Pública está submetida à Economia.

Como funciona, então, esse teatro grotesco, no contexto econômico?

A resposta que salta aos olhos, por óbvia, é acabar com a saúde e os hospitais públicos. Esse projeto foi anunciado pelo primeiro (des)ministro da Saúde, Henrique Mandetta, ao propor a privatização do SUS. Vários programas sociais também foram descontinuados: Mais Médicos, Atenção à Saúde Básica, Farmácia Popular, deixando claro que não há compromisso com o bem estar social. E tudo é feito em nome do contingenciamento dos recursos destinados à Saúde.

\footnotetext{
${ }^{18}$ General Pazuello, Folha. uol.com.br, 07.10.2020.

${ }^{19}$ Entrevista concedida a Datena. Congresso em Foco, 28.03.2020.

${ }^{20}$ Gazeta do Povo, 30.07.2017.
} 


\section{REVISTA DA ABRALIN}

Mas não só. Há outros fatores relacionados diretamente à pandemia que também incidem sobre a Pasta da Saúde, como podemos observar a seguir:

1. No dia 19.10.2020 21 , o presidente-capitão entrou novamente em confronto com a ciência, ao afirmar que "A vacinação não será obrigatória", contrariando infectologistas e virologistas que entendem ser a vacinação em massa crucial para controlar a pandemia. Como é possível interpretar essa declaração? Que não serão adquiridas doses da vacina em quantidade suficiente para imunizar toda a população? Que esse é um gasto muito grande e desnecessário? Ou essa é mais uma manifestação que se inscreve na série negacionista da ciência?

2. O Conselheiro da Segurança Nacional de Trump, em visita ao país, afirmou que "a parceria comercial com a China representa uma ameaça para o Brasil" 22 e, no dia seguinte, acusou a China de ter roubado a vacina ${ }^{23}$. Foi quanto bastou para que o (des)presidente decretasse:

SD25 - Não compraremos a vacina chinesa. O Brasil não será "cobaia" de ninguém. Não se justifica um bilionário aporte financeiro num medicamento que sequer ultrapassou sua fase de testagem. (Uol, 21.10.20)

A SD25 expõe algumas contradições, a saber:

a) A China pode ser um entrave comercial para o Governo americano, mas é um dos principais importadores da carne brasileira, para apenas levantar um ponto entre os muitos que poderiam ser explorados aqui. Para um país que valoriza suas exportações, como a SD1 deu a ver, como entender essa capitulação do (des)presidente? E como ficam seus "patrões" do agronegócio diante de tal decisão?

b) A vacina está sendo desenvolvida pela China em colaboração com o Instituto Butantan, e testada em hospitais de diferentes cidades brasileiras. Isso significa que há aporte financeiro brasileiro para essa etapa da pesquisa. Essa verba não conta? E o trabalho dos pesquisadores brasileiros deve ser descartado?

c) O (des)presidente gastou muito dinheiro para produzir a cloroquina sem que houvesse comprovação de sua eficácia e, agora, exige certificado de eficácia para adquirir a vacina que irá debelar a pandemia.

Frente a essas contradições, a vassalagem do (des)presidente frente aos Estados Unidos de Trump fica escancarada. E sua política de morte, uma vez mais, se faz visível.

O desfinanciamento da saúde pública, como se vê, não pode ser creditado exclusivamente ao fascismo. Esse desmonte é fortemente tributário da política econômica neoliberal e denuncia o caráter privatista do (des)governo, que entrega ao mercado o que a Constituição determina como dever do Estado. De modo que uma política de morte, própria ao fascismo, une-se a uma política neoliberal nesse projeto de desconstrução do SUS. Mas não só. É preciso somar a esses fatores, o negacionismo

\footnotetext{
${ }^{21}$ G1.Globo, 19.10.2020.

${ }^{22}$ Brasil de Fato, 21.10.2020.

${ }^{23}$ O Globo, 21.10.2020.
} 


\section{REVISTA DA ABRALIN}

da ciência e a submissão a Trump. Pode-se, pois, observar que a pandemia foi fortemente politizada no interior dessa pasta. E, nessa guerra, quem de fato sai perdendo, é a população brasileira.

$\mathrm{E}$, assim, chegamos ao quarto ato, realizado no Ministério do Meio Ambiente, pois não é possível ignorar a atuação do (des)ministro Ricardo Salles. Para tanto, limito-me às sugestões que fez na famosa Reunião Ministerial de 22 de abril:

SD26 - Nós temos a possibilidade nesse momento que a atenção da imprensa tá voltada quase que exclusivamente pro Covid [...] tá nos dando um pouco de alívio nos outros temas, e passar as reformas infralegais de desregulação, simplificação, todas as reformas [...] Tudo que a gente faz é pau no judiciário no dia seguinte. Então [...] precisa ir passando a boiada e mudando todo o regramento e simplificando normas [...] Agora é hora de unir esforços pra dar de baciada a simplificação que precisamos em todos os aspectos. (YouTube, Poder360)

Examinando a SD26, percebe-se que esse (des)ministro constitui um verdadeiro paradoxo, pois em lugar de proteger o meio ambiente, contraditoriamente, promove sua destruição. E, enquanto as barreiras legais vão sendo derrubadas, garimpeiros avançam em território indígena, o agronegócio desmata e queima a floresta amazônica e a fauna perece junto ela. Essa forma de tratar o patrimônio ambiental revela o alto apreço que o tenente-capitão nutre pelo agronegócio, pois esse setor avança pela Amazônia.

O mais inacreditável de tudo isso, é que esse (des)governo nega todas as evidências de destruição da Amazônia que lhe são apresentadas, seja pelo INPE $^{24}$, seja pela imprensa nacional e internacional, seja, ainda, por instituições internacionais, entrando em confronto com dirigentes de países como a França e a Alemanha, por exemplo, que bradam contra o desmatamento da Amazônia, a ponto de comprometer o acordo comercial entre da União Europeia e o Mercosul. O (des)presidente nega até mesmo as evidências das trágicas imagens registradas por satélite, colocando-se como vítima de uma pretensa campanha difamatória.

A prática discursiva do negacionismo tornou-se tão arraigada que não mais se limita a denegar os crimes da ditadura militar. Agora ela sobredetermina a práxis discursiva desse (des)governo como um todo. E o mais contraditório de tudo isso é que o negacionismo se produz à luz do Evangelho de João: "Conhecereis a verdade e a verdade vos libertará".

Com base no que precede, pode-se afirmar que se trata de uma política econômica neoliberal que visa ao lucro acima de tudo, que valoriza, em lugar da produção de conhecimento, o extrativismo, a agricultura, a mineração e a criação de gado, visando prioritariamente à exportação, em uma curiosa similitude com o Brasil Colônia. Mas será somente isso? Meu questionamento surge em decorrência de uma forte contradição que atravessa as práticas do capitão, no que tange a seu posicionamento frente a seus "patrões" (conferir SD1). Entre os "patrões" brasileiros e o "patrão" americano, é a esse último que o (des)presidente deve "maior" lealdade. Em virtude disso, impõe-se, então, uma pergunta:

\footnotetext{
${ }^{24}$ Instituto Nacional de Pesquisas Espaciais.
} 


\section{REVISTA DA ABRALIN}

Como interpretar seu lema "O Brasil acima de tudo e Deus acima de todos"? De que Deus fala o capitãopresidente quando fala de Deus? Seria o deus-mercado? Ou o deus EUA? Ou, ainda, ambos?

Na coxia desse teatro do grotesco - os bastidores do Planalto, do Congresso e dos gabinetes ministeriais - o poder trama constantemente a destruição de tudo o que foi construído ao longo de muitas décadas. Tudo está à venda.

Nesse ponto, trago uma manifestação bastante significativa do General Rêgo Barros que, até bem poucos dias atrás, era o porta-voz do (des)presidente. Era, porque o cargo de porta-voz foi extinto, com ele ainda exercendo a função. Na entrevista que o ex-porta-voz concedeu ao programa Conversa com Bial, ao ser questionado sobre a razão que levou o capitão a extinguir essa função, afirmou:

SD27 - Ele percebeu ou foi convencido por outras pessoas de que talvez fosse melhor ele exercer esta função de vender a mercadoria governo e presidente junto à sociedade. ${ }^{25}$

"Vender a mercadoria governo e presidente"? Vale dizer: tudo está à venda, inclusive o presidente e o governo! O Brasil está sendo oferecido em uma enorme liquidação. Observando a extensão desse desmonte, cabe lembrar Vladimir Safatle e sua noção de Estado suicidário. Trata-se, diz o autor, de um "ritual de liquidação de si em nome da crença na vontade soberana e na preservação de uma liderança que deve encenar seu ritual de onipotência" (SAFATLE, 2020). Dito diferentemente: desmontam, sucateiam e vendem tudo, visando ao lucro imediato, sem atentar, entretanto, que, ao final, nada restará, pois o Estado terá se suicidado.

\section{Suspendendo a reflexão}

De tudo quanto precede, é possível concluir que há um intenso processo de naturalização em torno de fatores vitalmente cruciais, postos em funcionamento pelo (des)governo: naturalização de saberes fascistas, produzidos a todo instante, sem nenhum pejo; naturalização do desmonte educacional, como se sucata fosse, para entregar a educação ao mercado; naturalização do desmonte da saúde pública, assumindo uma política da morte; naturalização da destruição de bens públicos, como o patrimônio ambiental e a biodiversidade, para entregá-los ao agronegócio; naturalização da liquidação do patrimônio cultural, tratado como inútil e "satânico"; naturalização das mortes; naturalização da precarização da vida do trabalhador. Esse complexo processo de desmonte naturalizado retrata, em todas as suas cores, a fisionomia do (des)governo que preside o Brasil e põe a nu a crise de civilização que o sistema neoliberal em seu entrelaçamento com saberes fascistas instituiu.

Concluindo: para interpretar esse (des)governo e seu teatro do grotesco, penso poder afirmar que ele apresenta uma dupla face. A primeira, de fachada, produz o teatro do grotesco, onde seus

\footnotetext{
${ }^{25}$ https://gshow.globo.com/progr./conversa-bial, 19.10.2020. Acesso em 20.10.2020.
} 


\section{REVISTA DA ABRALIN}

membros entram em polêmicas, produzindo, desse modo, uma cortina densa que encobre suas ações. Essa é a face que todos vêem, exposta pelos jornais, pelas TVs, pelas redes sociais. E, enquanto esse teatro do grotesco é assistido e comentado, a outra face, nas coxias, trabalha, quase silenciosamente, produzindo a meticulosa desconstrução do patrimônio científico, ambiental, educacional e cultural. Essa é a face oculta da liquidação cuidadosa em curso do próprio Brasil.

\section{REFERÊNCIAS}

ALTHUSSER, L. Aparelhos ideológicos de Estado. São Paulo: Martins Fontes, 1970 [1967]. 121p.

ALTHUSSER, L. Posições 1. Rio de Janeiro: Graal, 1978 [1973], 166 p.

ANSART-DERLEN, M. O ressentimento - as modalidades de seu deslocamento nas práticas revolucionárias. Reflexões sobre o uso da violência. In: BRESCIANI, S. ; NAXARA, M. (Orgs.). Memória e (res)sentimento. Campinas: Ed. da Unicamp, 2001. p.351-401.

COURTINE, J-J. A voz do povo. A fala pública, a multidão e as emoções na aurora da era das massas. In: COURTINE, J-J.; PIOVEZANI, C. (Orgs.). História da fala pública. Uma arqueologia dos poderes do discurso. Petrópolis, RJ : Vozes, 2015. p. 261-289.

DALTOÉ, A. da S. As metáforas de Lula: a deriva dos sentidos na língua política. 2011. 219p. Tese (Doutorado em Estudos da Linguagem). PPG/Letras, Universidade Federal do Rio Grande do Sul. Porto Alegre.

DUNKER, C. I. L. Prefácio à edição brasileira. In: ZIZEK, S. Covid-19 e a reinvenção do comunismo. São Paulo: Boitempo, 2020. Versão Online: https://books.google.com.br/books Acesso: 20.09.2020.

FREUD, S. Psicologia das massas e análise do eu. Porto Alegre: L\&PM, 2017 [1921]. 172p.

GADET, F; PÊCHEUX, M. O real da língua é o impossível. In: A língua inatingível. O discurso na história da linguística. Campinas: Pontes, 2004 [1981]. p. 51-53.

INDURSKY, F. Que sujeito é este? In: GRIGOLETTO, E.; DE NARDI, F. S.; SILVA SOBRINHO, H. F. (Orgs.). Silêncio, memória, resistência: a política e o político no discurso. Campinas: Pontes, 2019a. p. 79-117.

INDURSKY, F. O mal-estar na política e na cultura brasileiras, hoje. In: MITTMANN, S. ; CAMPOS, L.J. (Orgs.). Análise do discurso: da inquietude ao incômodo lugar. Campinas: Pontes, 2019b. p. 27-41.

INDURSKY, F. Os (des)caminhos do discurso político na contemporaneidade. In: GRIGOLETTO, E.; NARDI, F. DE (Orgs.). A análise do discurso e sua história: avanços e perspectivas. Campinas: Pontes, 2016. p. 65-87.

INDURSKY, F. As outras vozes e as feridas ainda abertas (Posfácio). In: INDURSKY, F. A fala dos quartéis e as outras vozes. $2^{\text {a }}$ ed. rev. ampl. Campinas: Ed. da Unicamp, 2013. p.323-342.

INDURSKY, F. A memória na cena do discurso. In: INDURSKY, F; MITTMANN, S.; FERREIRA, M. C. L. (Orgs.). Memória e história na/da análise do discurso. Campinas: Mercado de Letras, 2011. p.67-89. 


\section{REVISTA DA ABRALIN}

INDURSKY, F. Unicidade, desdobramento, fragmentação: a trajetória da noção de sujeito em Análise do Discurso. In: MITTMANN, S.; GRIGOLETTO, E.; CAZARIN, E. A. (Orgs.). Práticas discursivas e identitárias. Sujeito e língua. Porto Alegre: Nova Prova, 2008. p.9-33.

KLEMPERER, V. LTR, la lange du III ${ }^{e}$ Reich. Paris: Albin Michel, 1996.

LACLAU, E. A política como construção do impensável. In: CONEIN, B.; COURTINE, J-J.; GADET, F.; MARANDIN, J-M.; PÊCHEUX, M. (Orgs.) Materialidades discursivas. Campinas: Ed. da Unicamp, 2016. p.103-120.

MARX, K. O 18 brumário de Luís Bonaparte. São Paulo: Boitempo, 2011 ([1851/1852]. 174p.

MBEMBE, A. Necropolítica. São Paulo: n-1 edições, 2018.

MILNER, J-C. O material do esquecimento. In: Usos do esquecimento. Conferências do Colóquio de Royaumont. Campinas: Ed. da Unicamp, 2017. p.81-98.

PÊCHEUX, M. Análise automática do discurso. Trad.: Eni P. Orlandi e Greciely Costa. Campinas: Pontes, 2019 [1969]. 181p.

PÊCHEUX, M. Semântica e discurso. Campinas: Ed. da Unicamp, 1988 [1975]. 317p.

PIOVEZANI, C. Falar em público na política contemporânea. A eloquência pop e popular brasileira na idade da mídia. In: COURTINE, J-J.; PIOVEZANI, C. (Orgs.). Historia da fala pública. Uma arqueologia dos poderes do discurso. Petrópolis, RJ: Vozes, 2015. p.290-337.

SAFATLE, V. Benvindo ao Estado suicidário. n-1 edições, n.4. http://www.n-1edicoes.org. Acesso em 10.06.2020.

SOUZA, P. Sobre o discurso e o sujeito na voz. Línguas e instrumentos linguísticos. Campinas, n.34, jul./dez. 2014. p. 198-211. Versão eletrônica. Acesso em 15.09.2020.

VIDAL, D. O maldizer. In: CONEIN, B.; COURTINE, J-J.; GADET, F.; MARANDIN, J-M.; PÊCHEUX, M. (Orgs.). Materialidades discursivas. Campinas: Ed. da Unicamp, 2016. p.73-84.

ZOPPI-FONTANA, M. Língua política: modos de dizer na/da política. In: ZANDWAIS, A; ROMÃO, L. M. S. (Orgs.). Leituras do político. Porto Alegre: Ed. da UFRGS, 2011. p.65-82. 